\title{
Seguir e servir a Cristo pobre: juventude, ideais e renúncias na Toca de Assis Follow and serve Christ in poverty: youth, ideals and sacrifices in Toca de Assis
}

Rodrigo Portella*

\begin{abstract}
Resumo
Este estudo busca compreender a aderência de jovens a um instituto católico - Toca de Assis - que se caracteriza por adotar um estilo de vida configurado por radical pobreza, renúncia a bens e estudos formais e dependência exclusiva da providência divina, além de desenvolvimento de trabalho com pessoas em situação de rua. Busca entender a opção juvenil por um estilo rigoroso de vida religiosa a partir de propostas de vida contrastivas com a sociedade contemporânea e, de certo modo, com a própria Igreja, visando a identidades alternativas e fortes. Assim, o artigo desenvolve o tema Juventude - Toca de Assis, renúncia, pobreza - e tem por objetivo verificar as relações entre juventude, comportamento e adesão, e estilos de vida radicais. Usa, principalmente, a metodologia das ciências sociais. Tem por conclusão provisória a compreensão de que os jovens que aderem à Toca de Assis, ao renunciarem a bens materiais e estudo e ao assumirem uma vida de pobreza e solidariedade para com os pobres, estão em um movimento de contrastividade e contestação social, motivados por uma identificação com o Cristo sofredor.
\end{abstract}

Palavras-chave: Toca de Assis. Renúncia. Pobreza. Jovens.

\begin{abstract}
The present study aims to understand the adherence of youth people to a Catholic institute called Toca de Assis. This group adopts a lifestyle of radical poverty, wich calls for renunciation of material goods and also to formal studies. Participants in this group also claim rely solely on state of divine providence for their material survival. Young people in this group perform a work of assistance to people marginalized by society and to those who live at risk on the streets. The article seeks to understand the reasons for the choice of young people for a religious lifestyle so strict that contrasts with the lifestyle of contemporary society and in a sense, the Church itself, aiming at the formation of alternate identities. Thus, the article develops the theme "youth", "Toca de Assis", "resignation", and "poverty". The study aims, in short, to examine relationships between youth behavior and adherence to radical lifestyles; For this purpose, a methodology of social science is used. As in interim conclusion, this discussion indicates the following: youth people who adhere to Toca de Assis, renouncing material possessions, study, and assuming a life of poverty and solidarity with the poor, are in a movement of social protest and are motivated by an identification with the suffering Christ.
\end{abstract}

Keywords: Toca de Assis. Renunciation. Poverty. Youth.

\footnotetext{
Artigo recebido em 10 de fevereiro de 2012 e aprovado em 10 de abril de 2012.

* Doutor em Ciência da Religião pela Universidade Federal de Juiz de Fora. País de origem: Brasil. E-mail: rodrigo@portella.com.br
} 


\section{Introdução}

$\mathrm{Na}$ Europa medieval surgiram, no seio da Igreja Católica, as ordens religiosas conhecidas como mendicantes, através dos franciscanos, dominicanos, carmelitas e servitas. Em tendência contrária à dos mosteiros, as ordens mendicantes propuseram-se a caracterizar-se pela ausência de bens, pela pobreza, pela itinerância e pelo convívio e pregação junto ao povo. A fraternidade católica brasileira da Toca de Assis, por sua vez, apresenta-se como uma espécie de revival mendicante, ou restauradora, recriadora daqueles ideais medievais. Agregando um grande número de jovens, a Toca de Assis surge como espécie de neofranciscanismo, pois toma como principal referência a figura de São Francisco de Assis e seus ideais, buscando, inclusive, assemelhar-se ao movimento franciscano primitivo, seja no vestuário (hábito), seja na aparência de seus aderentes (tonsura, pés descalços, geralmente a barba rala nos rostos masculinos). Além disso, na atividade religiosa prática diária, busca, a Toca de Assis, acolher e atender, em serviços assistenciais, a população em situação de rua e pessoas doentes.

Este texto busca pinçar dois elementos que se fazem bastante presentes e visíveis na Toca de Assis: a juventude de seus aderentes e a renúncia a bens materiais e estudos formais, em um estilo de pobreza acentuada. São levantadas questões como a das relações entre estilos de vida juvenil e opção por uma vida de privações, pobreza e renúncia aos estudos. Quais são os significados dessas relações? Como caracterizar jovens que buscam uma experiência religiosa de renúncias e de partilha de vida com pessoas que vivem nas ruas das grandes cidades? É em busca desse novo perfil de jovens católicos que aderem a uma nova fraternidade franciscana que se desdobra este texto.

\section{Renúncia e pobreza entre jovens católicos da Toca de Assis}

Os jovens aderentes à Toca de Assis se tornam pobres. Digo "se tornam", pois mesmo pessoas pobres que adentram o instituto se tornam, por certo, mais pobres do que eram. Se em épocas passadas entrar para o convento ou mosteiro poderia significar ascensão social, ou oportunidade de casa e comida garantida, tornar-se toqueiro, ao 
contrário, significa descenso social e risco de nem sempre ter comida suficiente para a fome do dia, ou teto, quando o toqueiro dorme na rua junto àqueles com os quais se nivelou em pobreza. Renuncia, o toqueiro, às suas roupas e a muitos objetos pessoais que antes possuía. Se cultivava vaidades as abandonará, tonsurando sua cabeça e deixando, a mulher, os cabelos curtos e cobertos. O dinheiro não será mais próprio; tudo será em comum. Tudo ou o pouco que houver. Aprender-se-á a viver de esmolas, da boa vontade dos homens e dos céus. Cinema, teatro, diversões: somente aqueles permitidos e se houver alguma oportunidade, e geralmente não as há. Estudos formais estão fora de questão. Também a nojos e náuseas se deve renunciar, pois não os pode carregar o toqueiro, que terá que conviver com a imundície das ruas e com o mau cheiro e as feridas de tantas pessoas em situação de rua, das quais cuidará diuturnamente. E, frisando: estamos falando de adolescentes e jovens, envolvidos com um mundo de anseios, expectativas, e com a vida toda pela frente, o futuro a construir.

Ser jovem na contemporaneidade (só agora?) implicaria experiências radicais ou limítrofes (MARIZ, 2005). Dir-se-ia que implica experiências de ruptura (pela via da contestação). A Toca de Assis, até onde percebo, segue um pouco tal lógica. Seria a Toca de Assis formada por pessoas que, no veio das experiências limites, buscam alternativas radicais à sociedade como a temos, capitalista, consumista e hedonista? Afigurar-se-ia a Toca de Assis a movimentos sectários nesse corte com o mundo, por assim dizer? Guerriero (2006) coloca como característica de grupos sectários o abandono de emprego, estudos, nome de batismo e a ruptura com amigos.

Seguindo um pouco por tal trilha, é possível conjecturar que a Toca de Assis pode ser considerada um grupo contracultural. Para tanto, é preciso evidenciar uma característica marcante de seu éthos: a renúncia. O ideal de pobreza radical, de viver apenas da providência divina, demarca a renúncia às fontes produtivas de sustentação, apelando para a providência, para um estilo de vida livre de compromissos sociais convencionados, e, a partir de um rosto coletivista, a Toca de Assis poderia se inscrever enquanto grupo contracultural ao molde dos hippies ou movimentos similares surgidos nas décadas de 1960 e 1970 (OLIVEIRA, 2003). O estilo de vida de renúncia à sociedade de consumo, de bens, à lógica capitalista, e o viver em sua contramão pode ser interpretado como um "romantismo anticapitalista". Pois, se o capitalismo, filho dileto do processo de 
secularização, de certa forma contribui - em sua expressão tradicional, ao menos - para desencantar o mundo, um anticapitalismo vivencial e visceral não deixa de ser uma tentativa nostálgica de reencantamento do mundo (LÖWY, 1989). A rejeição ao trabalho produtivo convencional, às sociedades capitalistas modernas, e o cultivo da improvisação, ou da providência, são sinais que podem remeter ao que Maffesoli (2005) classifica como "vida improdutiva", ou seja, a negação do trabalho formal e do progresso como imperativos dando lugar a uma fruição do provisório e do instante, ainda que ancorados na certeza da providência.

O estilo de vida em renúncia também pode ser interpretado como reação à ditadura da racionalidade, do instrumentalismo e cálculo, visando a uma revalorização do místico, do imponderável (SANTOS, 1993). Movimentos de tipo - ou aproximação - milenarista ou romântico, de reforma, são detectados, pela sociologia, como expressões sociais de desejo de retorno ao passado original (MENDONÇA, 2004). Viver no Espírito, nos braços de Deus, implicaria essa renúncia sobre a própria vida, rumos e desejos, entregando-se totalmente a outro (OLIVEIRA, 2003).

O fato de que as pessoas abrem mão de usufruir o dinheiro, de possuí-lo, não tendo direito a usá-lo como quiserem (MARIZ, 2006a) gera, certamente, uma atitude contracultural. É a renúncia a toda uma sociedade - incluída a Igreja nela - que se move através do dinheiro e por ele, e que tem seu mote no consumo.

\section{Sociedade, trabalho e renúncia: conquistando outros horizontes}

Voltando à questão da renúncia a uma configuração de vida considerada "normal" pela sociedade, é preciso perguntar o que uma experiência de automarginalização do mercado de trabalho (renúncia aos estudos formais/profissionalizantes, presente na Toca de Assis), em faixa etária juvenil (de formação), e por tempo relativamente longo pode acarretar. Provavelmente, a irreversibilidade da opção de retorno a esse mercado. Geralmente, as pessoas que são recrutadas para movimentos de molde carismáticoproféticos tendem a ignorar carreira, distinções, hierarquias (BOURDIEU, 1978). Seria essa uma atitude de insensatez juvenil ou de protesto contracultural em relação a uma sociedade regida pela corrida ao mercado de trabalho e disputa nele através da formação e do 
desempenho? Mariz (2006a, p. 11), contudo, oferece uma pista de resposta interessante ao afirmar que:

\begin{abstract}
Viver em comunidade (de vida/religiosa) significa viver e trabalhar com metas outras além do aumento do consumo, ascensão social. A constatação e/ou intuição que essas metas, ditadas pela sociedade mais ampla, provavelmente serão frustradas podem gerar conflitos pessoais ou sociais e ameaçar a autoestima. A opção pela vida em uma comunidade pode evitar esse tipo de frustração.
\end{abstract}

Nesse sentido, a que se renunciaria? A um futuro seguro e confortável ou à falta de perspectivas sólidas e atraentes? Renunciando à dúvida e instabilidade de um futuro incerto e aderindo-se a uma comunidade ideal, mais se perde ou mais se ganha? No discurso ou lógica da renúncia está embutido um ganho. Deixa-se a família para ganhar outra. Renuncia-se ao mundo para ganhar o céu. Deixam-se objetivos de vida laica para se engajar em um objetivo/missão maior, divino. Para ter, é preciso renunciar. Mas deixar coisas para trás significa ganhar outro mundo, radical e diferente.

Nesse ínterim, é, também, preciso anotar que a sociedade atual, em seu multiculturalismo, já não indica caminhos seguros e definidos, mas joga indivíduos numa polifonia semântica de caminhos, onde há não uma orquestra organizada, mas uma dispersão, cacofonia de vozes. Nessa sociedade, cada um deverá cantar a sua própria canção, compor seu próprio repertório, que se juntará à cacofonia geral. Nesse sentido o multiculturalismo, as possibilidades mil desarticuladas oferecidas pela contemporaneidade, que acaba não apontando para lugar nenhum e não dizendo nada, representam o fim da utopia (BAUMAN, 2003). Para muitos jovens, viver em tal tipo de sociedade, inseridos nela, pode parecer desesperador e anômico. Ou bastante arriscado, para dizer o mínimo. Mais arriscado, talvez, do que aquilo que a Toca de Assis representa para seu estilo de vida. Já segundo o argumento de Berger (2004), deixar trabalho, estudo e família, deixar a sociedade com suas estruturas convencionais e viver em uma espécie de contracultura pode ser um meio de renegar a ausência de sentido, a dor, a frustração, justamente pelo viés de certa "autoaniquilação".

Há, sim, e isso é evidente, uma escolha, em princípio bem consciente, de viver uma vida pautada na diferença. Os jovens da Toca de Assis não são constrangidos a romper com a sociedade dominante e desviar-se de seus valores. O constrangimento e pressões são justamente no sentido contrário. Gozar a vida, cuidar da saúde e da boa forma do corpo, 
aparecer em flashes são os sinais da cultura dominante (LIPOVETSKY, 1989). Portanto, mais do que um jovem que frequenta bares, cursa universidade e adere às modas sociais, podemos dizer que jovens como os toqueiros, estes, sim, ao tomar um rumo tão díspar do convencionado como "normal" pela sociedade, é que fazem uma verdadeira opção. Opção não está, em princípio, na aderência aos rumos convencionados. Nesse caso, há uma inserção natural que é, de certa forma, a falta do optar, do decidir outros rumos. Jovens que entram na Toca de Assis são, talvez, os mais modernos jovens da modernidade, pois usam da reflexividade, do juízo e da opção para encarnar um modelo de vida altamente diferenciado do normatizado socialmente e altamente reflexivo, enquanto escolha justificada em contraste com certos modelos de sociedade e mesmo de Igreja.

Importa, aqui, compreender que grupos ligados à Renovação Carismática Católica (RCC) costumam ter maior contundência em suas críticas aos valores da sociedade secular do que outros grupos da Igreja (MARIZ, 2006b). E que, por isso mesmo, tomam atitudes mais radicais em relação à configuração de suas próprias vidas em contraste com a sociedade. E isso significa um alto grau de juízo, que se constitui em um elemento de alta reflexibilidade, e não em um desgosto puro e simples pela vida social normativa, ou em uma atitude masoquista ou de fuga do mundo.

\section{A inserção na comunidade e a renúncia ao mundo: os virtuosos}

Porém, quero voltar ao paradoxo da renúncia/desejo, perda/ganho. Quando um jovem diz que "renuncia ao estudo" (MARIZ, 2006a, p. 13), ele está, ao mesmo tempo, revelando um desejo. Se há renúncia, há desejo. Ou seja, estaria no horizonte de sonhos desses jovens uma formação, uma carreira profissional. Nesse sentido, a atitude contracultural não está tanto em desprezar as regras da sociedade, mas em sacrificar seus desejos - às vezes coincidentes com os fomentados pela sociedade - para aderir a um objetivo maior que contrasta, mesmo, com seus sonhos ou desejos. Por isso é renúncia e sacrifício, pois só se renuncia àquilo que se quer.

Essa entrega de vida é, como diz um comunitário carismático citado por Miranda (1999, p. 47), "na obra, para a obra e da obra". Isso significa dizer, mais especificamente no caso da Toca de Assis, que nada mais se faz e se visualiza nos horizontes de interesses que 
não a missão e carisma daquele universo assumido. Troca-se o senso da individualidade e de seus desejos pelo senso do coletivo e do desejo do coletivo. Dentro de uma perspectiva durkheimiana, pode-se dizer que o carisma do grupo, a efervescência do e no grupo é o que sustenta o elo entre os comunitários e os impele em força e ideal para suas devoções e serviços. Nesse sentido, é preciso considerar que sentimentos de forte pertencimento são característicos de minorias, dos que "nadam contra a corrente". Minorias cognitivas tendem a apertar laços de solidariedade e pertencimento e a criarem certo sentido de superioridade em relação aos demais, aos de fora (MARIZ, 2005).

Abandonar estudos e profissionalização para viver de doações constitui-se em virtuose religiosa (MARIZ, 2005) em uma atitude heroica que se faz na contramão social. Nesse sentido, há uma retórica, quase senso comum, sobre a capacidade dos jovens de doarem-se por uma causa (MARIZ, 2005). A figura do jovem é idealizada em um romantismo, como um herói, como alguém capaz de extremos, da santidade, da revolução, do martírio (MARIZ, 2005). Contudo, viver da providência teria dois lados: um de risco, do viver sem seguranças pré-determinadas, e outro, paradoxalmente, de segurança, de certa segurança ontológica que a communitas dá, que o grupo, envolvido emocionalmente em uma mesma causa e em uma mesma fé na providência, proporciona, inclusive criando um sentimento de pertença e segurança familiar-grupal que, talvez, alguns jovens não sentissem enquanto em seus lares de origem.

A Toca de Assis estabelece-se, em seu ideal vivencial de pobreza e renúncia, como uma communitas gerida por referenciais carismáticos. Geralmente, movimentos religiosos do tipo communitas, integrados por pessoas separadas, eleitas, diferenciadas e intimamente vinculadas ao grupo, são considerados sagrados justamente porque transgridem as estruturas institucionalizadas, no nosso caso, as sociais de referência de normalidade (TURNER, 1974). A estrutura social vigente pressupõe propriedade e, por isso, a communitas procura aboli-la (TURNER, 1974), diferenciando-se da sociedade normativa e criando um espaço alternativo em que os valores são transmutados: pobreza se torna riqueza, renúncia se torna libertação. Ainda segundo Turner (1974), também seriam características da communitas a ausência de posições sociais diferenciadas e, de certa forma, a ausência do trabalho formal como forma de suprir as necessidades. 


\section{A pobreza como experiência}

A Toca de Assis faz questão de ser visualizada e - por que não - admirada pela bravura sacrifical e virtuosa de seus membros. Há uma busca por internalizar a questão da bravura virtuosa por Jesus, entre os membros, e externalizá-la por meio de certa propaganda e divulgação. Na revista da organização, Toca para a Igreja, n. 59, em sua capa, há o chamado de reportagem "Ao encontro do papa: a pé de Minas a São Paulo". Tal reportagem é desenvolvida na página 5. A dramaticidade e o heroísmo da façanha não são diminuídos ou ocultados, como, talvez, pudesse omitir ou calar a humildade e discrição de um monge; mas proclamados e celebrados. Relata a Irmã X (Toca para a Igreja, 2006, p. 5):

Dormimos no chão de sábado para domingo. Tivemos que partilhar o que comer. Passamos frio e não dormimos direito [...]. Mas tudo era motivo de alegria! Me senti pobre, peregrina. Tudo o que comi foi providência, foi uma experiência de depender de Deus para tudo.

Chama a atenção no relato que, embora se faça questão de tornar pública a dificuldade de uma peregrinação a pé entre cidades longínquas, não há um tom de comiseração ou autopiedade. Ao contrário, os sofrimentos suportados são sinais de alegria e exaltação. O passar por situações limítrofes ou difíceis, e superá-las, vêm a confirmar o caráter de aventura e de entrega juvenil que se realiza nas experiências radicais por uma causa. E, aqui, a palavra "experiência" salta aos olhos. "Foi uma experiência de depender de Deus", diz a Irmã X (Toca para a Igreja, 2006, p. 5), que também afirma: "me senti pobre, peregrina" (Toca para a Igreja, 2006, p. 5). Não é isso que juventude e sensibilidades pós-modernas buscam, em conjugação? Sensações novas, diferentes, desafiantes, através de experiências que as provoquem? A própria palavra "experimentar" está, geralmente, carregada de sentidos como passageiro, efêmero, algo momentâneo, impermanente, além de poder conotar desafio, vivência, amadurecimento.

A palavra experiência tem muito contato com o universo juvenil. E com formas de vivência momentânea cheias de adrenalina e emoções. Experiência, nesse contexto, pede e aponta para emoções, sensações. Irmã $X$ diz ter se sentido pobre, peregrina. Foi uma experiência que deu uma sensação, que criou uma emoção, um clima. É interessante que essa irmã, que largou, talvez, a segurança de um lar familiar, de estudos, para ser toqueira, 
ou seja, fez-se pobre - ou mais pobre, caso sua origem já seja de classes sociais empobrecidas -, tenha dito que se sentiu pobre nessa experiência de peregrinação. Isso pode revelar que a pobreza, na Toca de Assis, é buscada como um ideal performático que tem que passar pelos sentidos, pela emoção.

Irmã $\mathrm{X}$ é pobre, pois depende de doações para sobrevivência e não tem bens pessoais no interior da Toca de Assis. Mas, talvez aqui esteja uma chave de leitura diferente para entender a pobreza da Toca de Assis, e, em princípio, não só na da Toca de Assis, mas também nas demais ordens e congregações religiosas católicas cujos membros fazem voto de pobreza. A pobreza por "opção" difere em muito da pobreza por condição social impingida, não optada. Quem se torna pobre por opção, geralmente - talvez na maior parte dos casos -, tem para onde voltar caso haja um posterior arrependimento quanto a essa opção. Uma pessoa que opte pela pobreza radical da Toca de Assis aos 16 anos, por exemplo, abandonando a casa familiar, aos 24 anos, se tiver arrependimento da opção tomada, pode deixar de ser pobre - ao menos na acepção da radicalidade da pobreza toqueira - e retornar, possivelmente, para a casa de familiares. Portanto, a pobreza é reversível e pode ser encarada como experiência, uma nova sensação, idealista ou não.

Já alguém que é pobre, ou melhor, miserável, por condição social-financeira e familiar, ou mesmo que não tem família, ou que tem uma família que o rejeita, como muitas das pessoas que estão em situação de rua, não tem para onde "voltar". Tais pessoas não vivem uma experiência ou têm uma sensação de pobreza (a ser celebrada), mas são de fato pobres. A pobreza, a miséria, o abandono, a rejeição, é uma realidade, dura realidade, e não uma "experiência" por que passam. Portanto, quem busca a pobreza por opção busca, consequentemente, uma sensação de pobreza.

Outra questão relativa à pobreza religiosa por opção, de religiosos, especificamente, é que a "providência" sempre costuma aparecer. Na verdade, a fé na providência é muito mais que um dado teológico, é um dado social. Em uma sociedade oficiosamente cristã e em um meio católico há uma rede de pessoas que se sensibilizam com a vida religiosa de pessoas que se doam altruisticamente aos mais necessitados. Além dos toqueiros leigos, que ajudam financeiramente a Toca de Assis, há as pessoas católicas que esporadicamente doam dinheiro e bens aos toqueiros, sensibilizadas com o trabalho assistencial deles e com a própria coragem que percebem em jovens que deixam tudo para servir aos necessitados e 
à Igreja. Portanto, quando a providência é certa, a sensação de pobreza pode ser, de certa forma, relativa. A pessoa é pobre, mas nada do que é necessário falta. A providência é infalível. Um miserável ou pobre por condições econômicas e sociais, atirado no meio da rua ou em um casebre no sertão nordestino, pode morrer de fome. Para estes, a providência pode faltar. Não são religiosos consagrados e reconhecidos, com uma teia católica e eclesial a abraçá-los, caso a "experiência" da pobreza ganhe ares de risco de morte. Também não são, em princípio, virtuosos religiosos admirados. Porém, penso que dificilmente se verá um toqueiro morrer de fome ou por falta de acesso a atendimento mínimo de saúde, por mais pobre, sacrificante e radical que seja em sua experiência. Portanto, a pobreza toqueira, idealizada, torna-se uma experiência a ser sentida. Uma sensação a ser buscada. Não deixa de ser, assim, uma performance, por mais sincera que seja.

De fato, na estrada, sozinhos, distante de suas casas, de seus colaboradores, de seus admiradores, em meio ao perigo, ao desamparo da "segurança" que seu meio e lugar de vida dá, o toqueiro pode dizer ter passado por uma experiência, um sentimento "de depender de Deus para tudo”. Fora do alcance de seu hábitat toqueiro, de suas tocas, Irmã $\mathrm{X}$ se viu solta no mundo, experimentando uma experiência de providência, digamos, mais radical ou imprevisível.

Outra questão para a qual chamo a atenção no relato é a da celebração do fato de se ter vivido uma sensação mais forte de pobreza, de abandono. A Toca de Assis faz questão de, com as melhores intenções, espetacularizar o limite, o heroísmo, a virtude, o sacrifício. Isso tem que ser partilhado. Tal partilha encoraja os demais, mostra a legitimidade do projeto, a possibilidade da vida heroica por Deus. É na conversação que se estrutura e fortalece o grupo.

\section{Entre a racionalidade e a providência}

A pobreza da Toca de Assis se conjuga com a providência, e se faz possível através dela. Não ter bens imóveis dos quais auferir rendas; não realizar trabalhos, formais ou informais, para ter remuneração; não estar na lógica de uma paróquia, dependente de dízimos e contribuições; toda essa ausência de fontes de renda leva a Toca de Assis, segundo seus adeptos, a depender somente de Deus, de sua bondade. Viver sem casa, tendo 
por casa o mundo, as ruas; viver sem bens; viver sem fonte de renda definida; viver, como diziam os antigos, ao "Deus dará".

Irmão T, em entrevista, revela:

Uma vez em Cotia a gente estava trocando as fraldas dos irmãos e acabaram as fraldas; eram 28 irmãos acamados [...] quando acabou a última fralda, passaram 10 minutos uma senhora ligou pra mim: "Irmão, eu queria dar uma doação, pode um carro vir buscar?", e eu disse "pode sim”, e eu me distraí e nem perguntei do que era a doação. Quando chegou eram 40 pacotes de fraldas.

O milagroso tem lugar na Toca de Assis e se chama providência divina. O dia a dia é gerido e explicado de forma encantada, para usar o termo já consagrado. Não há porque se preocupar, afinal, Deus é pai. Como por milagre, as coisas tendem a acontecer na hora certa e no lugar certo, pois que Deus estaria no comando de todas elas. O jovem $\mathrm{H}$, entrevistado, assevera que "para quem confia na providência, medo não pode existir". Nem medo e nem preocupação. Deus pode até tardar, mas não falha. Ir. F, ao seu turno, não poupa o verbo, em entrevista, ao falar da providência divina. Aponta como é "impressionante" o fato de chegarem pessoas, "na hora certa" para fazer doações em espécie, passar cheques, doar material de construção, comida.

A ruptura com a racionalidade moderna se dá, justamente, pelo fato de que nada é planejado, mas inspirado e revelado (OLIVEIRA, 2003). Ou seja, a providência e seus imponderáveis entram em cena com a pujança de uma negação da racionalidade, ou destronamento dela, ao mote pós-moderno. O deixar as opiniões próprias, as planilhas de planejamento, o abrir mão de decisões se associa à ideia do controle soberano de Deus sobre a vida das pessoas que requer, para tanto, a abdicação da tentativa de controle humano. É, portanto, uma contralógica diante da sociedade secular moderna e uma não institucionalização do saber, em uma abertura completa ao fluxo do Espírito Santo e da providência. Weber (apud LIBÂNIO, 2002, p. 67) afirma que no processo de secularização não há mais "forças misteriosas incalculáveis" e que "podemos, em princípio, dominar todas as coisas pelo cálculo [...] isso significa que o mundo foi desencantado”. Ora, então "existe uma semente nihilista na modernidade, que Anthony Giddens localiza no rompimento iluminista com a providência divina" (COSTA, 2009). A Toca de Assis se configuraria, então, em seu abandono de tudo e confiança estrita na providência divina, no 
abandono do cálculo, uma forte vertente de reencantamento, onde nada mais depende da racionalidade, mas da providência de Deus, que tudo supre. Assim,

[...] o carisma rejeita como indigna a obtenção racional e planejada de dinheiro, bem como toda atividade econômica racional [...] quando sua missão é de natureza pacífica, recebe os recursos econômicos necessários de patrocinadores individuais ou na forma de doações honoríficas. (WEBER, 2004, p. 325)

Nesse sentido, não se pode deixar de pensar, em paralelo, a crise do Estado no mundo capitalista neoliberal. $\mathrm{O}$ Estado ausente nas questões sociais relega à sociedade o cuidar dos pobres, o ser providência para eles. Pois que "a crise do Estado-Providência é um meio de disseminar e de multiplicar as responsabilidades sociais, meio de reforçar o papel das associações, cooperativas, das coletividades locais” (LIPOVETSKY, 1989, p. 125). Quando sai o Estado providente, quando o mais abandonado está literalmente ao "Deus dará", eis que este dá, em sua providência, através dos seus. Portanto, se a Toca de Assis é uma rede religiosa de providência para os abandonados pelo Estado, a mesma Toca de Assis é sustentada por uma rede religiosa de providência que se constitui em seu entorno, para apoio e sustento.

A providência pode ser interpretada como redes, laços que vão se criando a partir do grupo, em um mutualismo marcado pela afinidade do familiar, no nosso caso, do ideal (MAFFESOLI, 2006). Para o profeta e seus discípulos existe "o círculo de adeptos que o apoiam com alojamento, dinheiro, serviços” (WEBER, 1994, p. 310). Há, então, na Toca de Assis benfeitores que ajudam com uma quantia fixa todo mês; outros que assumem alguma demanda financeira mensal de uma casa, como conta de água ou de luz; outros que doam, mensalmente ou sazonalmente, cestas básicas, pacotes de fraldas ou ataduras.

O viver ao "Deus dará" pode conotar uma crítica à sociedade do trabalho, da produção, do acúmulo, capitalista, enfim. Como, também, pode revelar um modo contracultural de vivência, em que a preocupação com tempo e compromissos formais ganha lugar secundário. Como contraidentidade, isto é, como resposta à identidade forjada pelo Ocidente capitalista contemporâneo, consumista, hedonista, o toqueiro, ao molde do monge dos primeiros tempos do cristianismo, concebe-se como um peregrino por esta terra, e sua essência é a ruptura com este mundo - mundanismo - e o movimento desprendido dele à outra vida (SODRÉ, 2004). De forma reativa aos modelos civis e, também, 
eclesiásticos burocratizados, o toqueiro requer para si uma identidade fluida que contrasta com as exigências da moderna sociedade:

\footnotetext{
De dentro da sociedade moderna, tecnológica, eficiente, produtiva sob o império da razão instrumental, emergem pessoas que buscam uma alternativa a ela. Os campos da religião, da estética, da lúdica atraem-nos. E quando a religião se veste de beleza, a atração é ainda maior. (LIBÂNIO, 2002, p. 80)
}

A Toca de Assis parece carregar, em si, esse charme de uma vida religiosa estética e lúdica, ou, para ser mais preciso, ideal. Embora dura no seu dia a dia, a beleza do ideal se faz presente em toda a estética e prática conduzida na Toca de Assis: viver sem se preocupar com o dia de amanhã, sabendo que Deus tudo provê; o viver jovem entre irmãos imbuídos de uma mesma verdade e lutando em favor dela; o viver adorador em presença constante do Deus.

A ideia de providência carrega em si uma "ordem de dignidade diferente" da ordem natural (WEBER, 1994, p. 334). Assim, também a ordem do dia a dia, na Toca de Assis, tem um status diferente daquela do mundo racionalizado em suas atividades. Também quanto a esse ínterim, embora haja significativas diferenças em relação aos hippies dos anos 1960-70, pode-se fazer pontes entre eles e a Toca de Assis, a partir do conceito de communitas, levando-se em conta um caráter contestador do mundo - e, de certa forma, da Igreja - nas expressões de espontaneidade e não previsibilidade (TURNER, 1974).

\section{Os pobres são os professores: a Toca de Assis e os estudos formais}

A providência também atua no espectro cognitivo na Toca de Assis. Como já mencionado, a Toca de Assis cultiva um antiacademicismo. Estudos formais não são recomendados aos toqueiros. O discurso que se ouve na Toca de Assis é o de que estudos formais, dentre eles o da teologia, são proibidos porque o carisma da Toca de Assis é cuidar dos pobres, não formar padres. E, no ritmo de trabalho e dedicação que os irmãos têm, não seria possível conciliar estudos acadêmicos e serviço à população em situação de rua. $\mathrm{O}$ aprendizado essencial do toqueiro é o que ele teria junto à adoração eucarística e junto aos pobres. De fato o sítio da Toca de Assis afirma que "os pobres são os nossos livros”, ou 
seja, quem dá a real formação no dia a dia aos toqueiros. Ou, como costumava dizer o Pe. Roberto Lettieri, citado por toqueiros, "nossa faculdade é a rua".

É interessante notar certo paralelismo entre o dizer que a faculdade é a rua e o dizer que a faculdade é, ou foi, a vida - que tantas pessoas, sem ou com pouco estudo formal, afirmam -, no intuito de expressar que, embora não tenham estudado, têm uma sabedoria que a Academia, ou a teoria, não podem dar. Jovens, muito jovens às vezes, impedidos de estudar e que deram livre assentimento a esse impedimento recorrem à máxima de que a faculdade é a rua, talvez para afirmar uma sabedoria superior à dos doutos e estudados. $\mathrm{E}$ para superar críticas, suspeitas e conflitos em suas relações com as demais forças e representantes eclesiásticos, que veriam na falta de estudos dos toqueiros um déficit perigoso. Mas a recusa aos estudos formais, claro, transcende essa questão.

O vocacionado, ao adentrar a Toca de Assis, percebe valores do seu passado recente - e para pessoas tão jovens só há mesmo passado recente, ou o ontem - como nocivos ou, então, sem verdadeira importância. O que ontem era sonho e esforço torna-se, a partir da Toca de Assis, insignificância. Conforme descreve, em entrevista, o postulante Y:

Eu via que o estudo [faculdade de turismo] era só uma conveniência para mim, eu estava vendo como era meu egocentrismo, era uma satisfação pessoal, apenas [...] e hoje eu sei que a minha satisfação pessoal pode aliviar a dor de um outro, eu estou muito satisfeito na Toca, muito feliz na Toca. Eu sei que esta minha satisfação não é só minha.

Há uma troca preciosa aqui preconizada: abandona-se um sonho pessoal para fazer parte de um sonho coletivo. Mesmo um curso de medicina ou enfermagem pode ser visto como sonho pessoal, dado que, apesar de o exercício da profissão poder estar a serviço do alívio do sofrimento de outras pessoas, os cursos são vistos como uma profissão que, em última instância, serve para que se aufira lucros pessoais, senão prestígio próprio. Também percebo certo veto, ou constrangimento, àquilo que possa dar satisfação pessoal, ao menos fora do âmbito estritamente religioso. Estar em um projeto profissional separado de uma causa sagrada é tido como satisfação própria egocêntrica; porém, fazer parte de um projeto coletivo de cunho religioso e de cunho social, ao levar alívio (e Deus, por suposto) a outrem, provoca uma satisfação lícita.

Contudo seríamos ingênuos ao resumir a recusa aos estudos formais a essa questão. A Toca de Assis vive em um dossel sagrado, em que quase (?) tudo tem uma causa, oculta 
ou revelada, em referência ao âmbito do sagrado ou do demoníaco. Os estudos estão, também, aí. As palavras do Pe. Roberto são diretas: "O Brasil está se tornando um dos países mais satânicos da América Latina, através de muitas universidades, onde muitos jovens têm aprendido a não acreditar no Senhor” (TOCA PARA A IGREJA, 2004, p. 6). O tom é generalizante. Não se fala de certos cursos em específico, ou de professores hereges, agnósticos ou ateus a influenciar seus pupilos. O problema são as "muitas universidades". Ou seja, o saber acadêmico, em si, representado por elas. O saber acadêmico é venenoso à alma, pois incutiria a visão racional e empírica do mundo. A razão é perigosa, principalmente sem Deus.

A desqualificação das expressões intelectuais da fé vai ao encontro da valorização das manifestações sensíveis, diretas, da presença do divino (HERVIEU-LÉGER, 1997). Assim foi no franciscanismo primitivo e assim pode se dar em pessoas ou grupos que recusam a mediação da razão para um encontro com Deus.

Os livros e sua muita cultura e razão levariam para longe de Deus e para longe dos pobres. E, se leva para longe de Deus, desencanta o mundo. Ao introduzir a razão analítica e crítica, cria perigosas rachaduras na abóbada celeste. "A tensão entre a religião e o conhecimento intelectual destaca-se com clareza sempre que o conhecimento racional, empírico, funcionou coerentemente através do desencantamento do mundo e sua transformação num mecanismo causal" (WEBER, 2002, p. 244). Na contramão da racionalização moderna, que não considera mais qualquer autoridade como legítima apenas pela tradição ou carisma de um líder, exigindo que as legitimações se deem pelo discurso racional (MARIZ, 2003), a Toca de Assis acentua a tradição e o carisma de um líder como pontos suficientes para legitimações absolutas de seu programa religioso. O próprio Weber (2002) anota que, na adesão aos profetas, o conteúdo emocional é considerado o primordial, sendo a racionalização ("pensamentos”) sobre este expressão secundária. Questionar e questionar-se, em assuntos ligados à Igreja e doutrina, é visto como perigosa tentação demoníaca. Portanto, a soma é fácil: questionamento racional + aumento de ofertas de cursos acadêmicos, que veiculariam tais questionamentos = expansão do reino demoníaco. O religioso toqueiro, virtuoso que é, busca estar longe dessa teia aparentemente inofensiva do Diabo: 
Eu já consagrei a minha vida a Deus. Então o demônio investe mais, com questionamento. Mas como eu digo, um religioso penitente, o demônio nunca consegue entrar por questionamento, porque ele não tem tempo para questionar, está sempre em adoração, em serviço, em reparação. A vida dele, ele acorda pensando em Deus, enfim, ele só vê Deus na frente dele, diz Irmão T, em entrevista.

“O guerreiro, não o literato, é o ideal da religiosidade" (WEBER, 1994, p. 414). Com essa frase brilhante, Weber acerta na mosca, como de hábito, na questão. Os toqueiros são guerreiros, exército de Deus em adoração e reparação. Os livros os distrairiam da luta, fariam com que fossem menos viris, que tivessem menos atenção ao que realmente importa. Inclusive os estudos teológicos. Mas estes por motivo maior. A teologia, para a Toca de Assis, vive grave crise, deixando-se permear pela dúvida metódica, pela influência das ciências humanas e sociais - leia-se não sagradas - nela; pela análise crítica da tradição e por militâncias e ideias esquerdistas que seriam estranhas ao depósito da fé católica. É a desconfiança quanto à racionalização teológica e quanto ao saber formalizado, entendido como ameaça, conforme já nos aponta Hervieu-Léger (1997), referindo-se a grupos que se guiam pelo emocionalismo religioso.

A dúvida, sobretudo a metódica, é radical. Chega a duvidar de si mesma. O ceticismo - que não era, parece, a intenção inicial de Descartes - por essência, não tem limites; ativado, mesmo que por prudência, não volta atrás e é avassalador. Destrói o "taken-for-granted". (COSTA, 2009)

Ou, ainda, pode-se dizer que "a modernidade é caracterizada pela necessidade de autoconhecimento e pela capacidade de determinação da própria trajetória de vida. Movimentos que recusam a razão cartesiana, a técnica, enfim, a importância do conhecimento teórico para a felicidade e o progresso são, no dizer de Silva e Costa (2004), movimentos antiprometeicos, isto é, que recusam o legado de Prometeu de ainda envolver a sociedade e cultura técnica e intelectual em que estamos, que visa ao conhecimento intelectual como fonte de bem-estar e progresso humano e técnico. Abjuram por um lado a roubar o fogo dos deuses, mas, ao mesmo tempo, participam desse fogo (experiência religiosa) pela via emotiva, e não intelectiva. Uma característica de retorno a um estado pré-moderno (e pós) é a recusa da razão como acesso ao conhecimento. Ao se recuperar uma miríade de ritos, mitos e símbolos como articuladores absolutos e únicos da vivência humana, e interditar estudo e conhecimento acadêmico e científico, a Toca de Assis se 
desvincula do paradigma racional moderno e se entrincheira no paradigma do mito (SANCHIS, 1993). Ou, segundo Hervieu-Léger (apud CAMURÇA, 2003), as formas não verbais de intensidade afetiva dão o tom e têm proeminência sobre qualquer outra forma de se vivenciar a fé, particularmente a intelectual.

\section{Conclusão}

Se, por um lado, a faixa etária juvenil não pode ser refém de tipologias e representações idealizadas que se constroem no sentido de uma classificação geral do que seja ser jovem, sem a percepção da diversidade que há entre diferentes modelos de juventude e de sensibilidades juvenis, por outro lado, há quem veja um traço comum aos diversos tipos de juventude: “A efervescência vital, o querer viver intensamente sem querer recusar o risco do ato heroico ou do anti-herói, do mostrar-se socialmente", como identifica o sociólogo Carlos Espinheira (2006, p. 32). Segundo Galland (1997), uma das características fortes no período juvenil, ainda que ele esteja a falar da força secularizada e da juventude agnóstica, é o humanismo e a solidariedade humana como pontos de contato com identificação de atitudes religiosas, ou espiritualizadas.

A Toca de Assis, como movimento que muito agrega os jovens, tem nesse ponto um veio atrativo forte do ponto de vista simbólico. Noto que os toqueiros e toqueiras são jovens que, na Toca de Assis e em sua função de cuidado dispensada aos moradores de rua, adquirem uma sensibilidade e maturidade grandes no que tange ao sentir o drama da miséria social e humana. E, nesse sentido, assumem, tais jovens, para suas próprias vidas a opção por renunciar a uma ordem social excludente e, renunciando a bens e estudos, como que se solidarizam com aqueles aos quais se dedicam, excluídos, não por opção, mas pela vida e suas intempéries, de bens, família, nome, formação, emprego.

Poderiam, esses jovens, estar em uma ONG, nos Médicos Sem Fronteiras, na Cruz Vermelha, em um trabalho de solidariedade anônimo. Porém, ser percebido pelos outros como fazendo parte de uma identidade e ação crística tem, certamente, outro poder para o jovem cristão, como assume uma toqueira ao dizer que é "uma alegria muito grande fazer parte da Fraternidade, e de ser, pelo menos um pouquinho, Jesus para os irmãos que sofrem" (FRATERNIDADE, 2005, p. 25). 
Ser um Cristo para o Cristo sofrido, em renúncia, em opção pela pobreza, pela informalidade, pela vida dependente da providência. O jovem toqueiro, assim, se aproxima do místico altruísta de Weber, mas um místico cuja referência está radicalmente em Jesus (e, por isso, exerce sua caridade através da Toca de Assis, e não da Cruz Vermelha, por exemplo). Afinal "o místico benevolente dá a sua camisa quando qualquer pessoa que lhe cruza o caminho acidentalmente lhe pede o paletó - e simplesmente porque lhe cruza o caminho [...] é uma dedicação [...] não pelo homem, mas pela devoção simplesmente" (WEBER, 2002, p. 232). Dedicação, renúncia, pobreza não pelo homem, mas pela devoção, destaco. Por Cristo, com Cristo, em Cristo.

\section{REFERÊNCIAS}

BAUMAN, Zygmunt. Comunidade: a busca por segurança no mundo atual. Rio de Janeiro: Jorge Zahar, 2003.

BERGER, Peter. O dossel sagrado: elementos para uma teoria sociológica da religião. São Paulo: Paulus, 2004.

BOURDIEU, Pierre. A economia das trocas simbólicas. São Paulo: Perspectiva, 1978.

CAMURÇA, Marcelo Ayres. A sociologia da religião de Danièle Hervieu-Léger: entre a memória e a emoção. In: TEIXEIRA, Faustino (Org.). Sociologia da religião: enfoques teóricos. Petrópolis: Vozes, 2003, p. 249-270.

COSTA, Joaquim. Sociologia da religião: apontamentos. Aparecida: Santuário, 2009.

ESPINHEIRA, Carlos. A universalidade dos usos de drogas: o lugar das drogas na sociedade pós-moderna. In: SIQUEIRA, Domiciano (Org.). Mal(dito) cidadão. São Caetano do Sul: King Graf, 2006, p. 28-39.

FRATERNIDADE de aliança Toca de Assis. Mundo e Missão, São Paulo, ano 12, n. 95, p. 24-26, set. 2005.

GALLAND, Olivier. Sociologie de la jeunesse. Paris: Armand Colin, 1997.

GUERRIERO, Silas. Novos movimentos religiosos: o quadro brasileiro. São Paulo: Paulinas/PUC-SP, 2006. 
HERVIEU-LÉGER, Daniele. Representam os surtos emocionais contemporâneos o fim da secularização ou o fim da religião? Religião e Sociedade, Rio de Janeiro, v. 18, n. 1, p. 3148, 1997.

LIBÂNIO, João Batista. A religião no início do milênio. São Paulo: Loyola, 2002.

LIPOVETSKY, Gilles. A era do vazio: ensaio sobre o individualismo contemporâneo. Lisboa: Relógio D’Água, 1989.

LÖWY, Michael. Redenção e utopia: o judaísmo libertário na Europa Central. São Paulo: Companhia das Letras, 1989.

MAFFESOLI, Michel. A sombra de Dionísio. São Paulo: Zouk, 2005.

MAFFESOLI, Michel. O tempo das tribos: o declínio do individualismo nas sociedades de massa. Rio de Janeiro: Forense Universitária, 2006.

MARIZ, Cecília Loreto. A sociologia da religião de Max Weber. In: TEIXEIRA, Faustino (Org.). Sociologia da religião: enfoques teóricos. Petrópolis: Vozes, 2003, p. 67-93.

MARIZ, Cecília Loreto. Comunidades de vida no Espírito Santo: juventude e religião. Tempo Social, São Paulo, v. 17, n. 2. p. 253-273. 2005.

MARIZ, Cecília Loreto. Comunidades de vida no Espírito Santo: um novo modelo de família? Rio de Janeiro: 2006a, 16 p. Texto não publicado.

MARIZ, Cecília Loreto et al. Fraternidade Toca de Assis: os virtuosos católicos. In: Congresso Latino-Americano sobre Religião e Etnicidade, 2006, São Bernardo do Campo. Anais ALER, São Bernardo do Campo: Umesp, 2006b. CD-ROM. 11pp.

MENDONÇA, Antonio Gouvêa. A experiência religiosa e a institucionalização da religião. Estudos Avançados, São Paulo, v. 18, n. 52, p. 29-46, 2004.

MIRANDA, Júlia. As linguagens da Renovação. In: MIRANDA, Júlia. Carisma, sociedade e política: novas linguagens do religioso e do político. Rio de Janeiro: Relume Dumará, 1999, p. 46-57.

OLIVEIRA, Eliane Martins. O mergulho no Espírito de Deus. Diálogos (im)possíveis entre Renovação Carismática Católica e a Nova Era na Comunidade de Vida no Espírito Canção Nova. Dissertação (Mestrado em Ciências Sociais - Universidade do Estado do Rio de Janeiro), Rio de Janeiro, 2003. 
SANCHIS, Pierre. Catolicismo, entre tradição e modernidades. Comunicações do ISER, Rio de Janeiro, n. 44, p. 8-24, 1993.

SANTOS, Boaventura de Souza. Modernidade, identidade e a cultura de fronteira. Revista Crítica de Ciências Sociais, São Paulo, n. 38, p. 11-39, dez. 1993.

SILVA E COSTA, Manuel. Religião e sociedade: a eficácia da religião e a religião da eficácia. In: RODRIGUES, Donizete (Org.). Em nome de Deus: a religião na sociedade contemporânea. Porto: Afrontamento, 2004, p. 121-134.

SODRÉ, Olga. Globalização e pluralismo: guerra e violência ou paz e diálogo. In: PEREIRA, Mabel Salgado; SANTOS, Lyndon (Org.). Religião e violência em tempos de globalização. São Paulo: Paulinas/ABHR, 2004, p. 11-52.

TOCA PARA A IGREJA. Revista mensal da Fraternidade de Aliança Toca de Assis. Campinas, n. 43, 2004.

TOCA PARA A IGREJA. Revista mensal da Fraternidade de Aliança Toca de Assis. Campinas, n. 59, 2006.

TURNER, Victor. O processo ritual: estrutura e antiestrutura. Petrópolis: Vozes, 1974.

WEBER, Max. Economia e sociedade. Brasília: Ed. UnB, 1994, v. 1.

WEBER, Max. Economia e sociedade. Brasília: Ed. UnB, 2004, v. 2. 